\title{
PENERAPAN METODE PEMBELAJARAN WHOLE BRAIN PADA MATA KULIAH TELAAH MATEMATIKA SD
}

\author{
Siti Napfiah \\ IKIP Budi Utomo Malang \\ napfiahsiti@gmail.com
}

\begin{abstract}
ABSTRAK
Penelitian ini ditujukan untuk menerapkan pembelajaran whole brain pada mata kuliah Telaah Matematika SD. Metode pembelajaran whole brain memberikan cara pemanfaatan manajemen kelas yang baik sebagai dasar proses pembelajaran. Jika manajemen kelas dapat terkelola dengan baik, maka mahasiswa dapat merasa nyaman untuk mengikuti proses pembelajaran. Selanjutnya metode ini menekankan seorang pendidik untuk melakukan pengajaran dengan memanfaatkan kegiatan visual, audio dan kinestetik secara bersama, sehingga kedua bagian otak dapat bekerja secara maksimal. Pendidik harus menggunakan media pembelajaran dan gerakan-gerakan yang menarik dalam penyampaian materi dan dituntut untuk melibatkan peserta didiknya ke dalam setiap pembelajaran. Tujuan penelitian ini adalah untuk mendeskripsikan metode pembelajaran whole brain yang dapat meningkatkan hasil belajar mahasiswa. Jenis penelitian ini adalah penelitian tindakan kelas. Metode pembelajaran yang dapat meningkatkan hasil belajar mahasiswa adalah metode pembelajaran whole brain yang mana pengelolaan manajemen kelas harus tertata dengan baik serta peserta didik harus diajak melakukan kegiatan audio, visual, dan kinestetik secara bersama-sama. Berdasarkan hasil tes diketahui bahwa lebih dari 50\% mahasiswa di kelas memperoleh skor lebih dari 75. Dengan metode pembelajaran whole brain yang melibatkan keseluruhan indra yang merangsang kedua bagian otak bekerja secara maksimal dan pengaturan manajemen kelas yang baik maka proses pembelajaran matematika dapat diterima oleh peserta didik dengan baik.
\end{abstract}

Kata Kunci : Metode pembelajaran whole brain, Telaah Matematika SD, Hasil belajar mahasiswa

\section{PENDAHULUAN}

Kualitas pendidikan menentukan kualitas sumber daya manusia suatu negara. Salah satu faktor penentu kulitas pendidikan adalah mutu pembelajaran. Mengingat pentingnya memperhatikan kondisi pembelajaran, maka kualitas pembelajaran harus ditingkatkan agar mutu pendidikan semakin meningkat.

Tugas pendidik maupun pengajar adalah memberikan kemudahan belajar kepada peserta didik agar mereka mampu berinteraksi dengan lingkungan sehingga terjadi perubahan perilaku ke arah yang lebih baik (Mulyasa, 2008:178). Kriteria keberhasilan proses pembelajaran tidak hanya diukur dari sejauh mana peserta didik telah menguasai materi pelajaran, akan tetapi juga diukur dari sejauh mana peserta didik telah melakukan 
proses belajar. Dengan demikian pendidik tidak lagi berperan hanya sebagai sumber belajar, akan tetapi berperan sebagai orang yang membimbing dan memfasilitasi agar peserta didik mau dan mampu belajar. Begitu pula sebagai seorang dosen sebaiknya memberikan bekal metode pembelajaran yang berkualitas kepada mahasiswa dimana mahasiswanya merupakan calon pendidik generasi selanjutnya.

Berdasarkan Uno (2006:17-18) metode pembelajaran memiliki tiga tahapan penting, yaitu (a) pengorganisasian, kegiatan menentukan dan memilah isi atau materi yang akan diajarkan, (b) penyampaian, kegiatan menyampaikan materi dengan metode yang tepat, dan (c) pengelolaan, kegiatan manajemen kelas untuk menata interaksi agar terjadi timbal balik dalam proses pembelajaran.

Seiring dengan perkembangan zaman, metode pembelajaran menjadi sangat bervariasi. Metode pembelajaran tradisional menekankan kepada metode pembelajaran ceramah dimana peserta didik harus mendengarkan bahkan mengingat apa yang disampaikan. Sedangkan pada perkembangan modern, metode pembelajaran yang baik menuntut pendidik untuk melibatkan peserta didik dalam proses pembelajaran agar peserta didik mendapatkan pengalaman dan pemahaman konsep pembelajaran yang nyata. Seperti yang diungkapkan Sanjaya (2007:145) bahwa keberhasilan implementasi dari metode pembelajaran yang digunakan secara tepat oleh pendidik dapat terlihat dari setiap hasil pembelajaran peserta didik.

Salah satu metode pembelajaran yang dapat mendukung hal tersebut adalah metode pembelajaran whole brain. Metode pembelajaran whole brain merupakan metode pembelajaran berasal dari Amerika yang dikembangkan oleh negara-negara barat yang dapat diadopsi oleh institusi-institusi pendidikan di Indonesia. Melalui metode pembelajaran whole brain, peserta didik dapat lebih berkonsentrasi karena metode ini menggunakan keseluruhan kemampuan audio, verbal, dan visual sehingga manajemen kelas dapat diatur dengan baik dan mudah. Di dalam Kamus Lengkap Terjemahan Inggris - Indonesia (2004:493,36) whole (kata benda) berarti keseluruhan dan brain (kata benda) berarti otak. Maka whole brain dalam bahasa Indonesia berarti keseluruhan otak.

Otak merupakan bagian penting dalam tubuh manusia. Otak berfungsi untuk mengendalikan semua fungsi tubuh dan merupakan pusat dari keseluruhan tubuh manusia. Otak manusia terdiri dari dua bagian utama yaitu otak kanan dan otak kiri dengan fungsi yang berbeda. Otak kiri digunakan untuk pembelajaran yang pasti atau eksak seperti pembelajaran matematika, sedangkan otak kanan digunakan untuk pembelajaran kreatif 
yang berhubungan dengan seni, musik, atau gambar (Rose \& Nicholl, 2002:54). Rose dan Nicholl (2002:55) juga mengatakan bahwa ketika mendengar sebuah percakapan, otak kiri berkonsentrasi pada isi percakapan, sementara otak kanan memperhatikan bagaimana ia diucapkan (emosi). Perbedaan fungsi kedua bagian otak ini harus diketahui dalam proses belajar, karena perbedaan itu menyebabkan kemampuan yang berbeda pula dari setiap orang.

Walaupun kedua bagian otak manusia memiliki bagian dan fungsi yang berbeda, namun jika keseluruhan bagian otak itu dapat difungsikan bersama-sama dalam pembelajaran, maka dapat menghasilkan pembelajaran yang maksimal. Seperti halnya, pada saat kita mendengarkan lagu, otak kiri akan bekerja memahami lirik lagunya, sedangkan otak kanan akan memahami melodi atau irama musiknya (Rose \& Nicholl, 2002:55).

Dengan mengkolaborasikan kedua otak dalam pembelajaran, memanfaatkan kegiatan visual, audiotori, dan kinestetik maka otak seseorang dapat berkembang dengan baik dalam suatu pola pemikiran yang cermat dan teliti daripada hanya sekedar mendengar tanpa memahami secara mendalam suatu pembelajaran (Jensen, 2010:16). Maka dari itu, akan ideal jika otak kiri dan otak kanan seimbang dan berfungsi secara optimal, dengan begitu akan menghasilkan seseorang yang cerdas dan dapat bersosialisasi dengan baik.

Biffle (2013:20) juga menyatakan bahwa otak memiliki dua bagian penyimpanan ingatan atau memori yaitu memori jangka pendek dan memori jangka panjang. Memori jangka pendek hanya dapat menyimpan sesuatu yang pendek dan bersifat relatif singkat, sedangkan memori jangka panjang dapat menyimpan sesuatu yang panjang dan bersifat lama tanpa menggeser memori yang sebelumnya. Suatu pembelajaran yang menarik dengan menggunakan kedua otak secara maksimal dan dilakukan secara berulang-ulang dapat tersimpan pada memori jangka panjang seseorang.

Pembelajaran di tingkat Sekolah Dasar merupakan tahapan penting bagi peserta didik karena proses pembelajaran pada tahap ini dapat mempengaruhi pola belajar untuk tahap selanjutnya. Pada tingkat awal, pemahaman peserta didik yang benar terhadap suatu konsep sangat penting sebagai modal dasar bagi penguasaan konsep yang lebih luas. Oleh karena itu calon pendidik yang akan terjun di Sekolah Dasar harus menguasai metode pembelajaran yang bagus dalam pembelajaran.

Mata kuliah Telaaah Matematika SD membekali mahasiswa Program Studi Pendidikan Matematika yang memilih mengajar di Sekolah Dasar. Mata kuliah ini 
dilaksanakan dalam rangka mempersiapkan calon pendidik yang akan terjun di institusi Sekolah Dasar agar memiliki bekal untuk mengajar nantinya. Bekal tersebut meliputi pengelolaan kelas atau pembelajaran di Sekolah Dasar. Contohnya cara memanajemen pembelajaran sesuai dengan kondisi atau umur peserta didik dan menangani atau menghadapi peserta didik di tingkat Sekolah Dasar. Selain itu juga dipelajari konsep materi matematika m di tingkat Sekolah Dasar mulai dari kelas I hingga kelas VI sesuai kurikulum.

Berdasarkan paparan di atas, rumusan masalah dalam penelitian ini adalah bagaimana penerapan metode pembelajaran whole brain pada pembelajaran Telaah Matematika Sekolah Dasar. Sedangkan tujuan penelitian ini adalah untuk mendeskripsikan penerapan metode pembelajaran whole brain pada pembelajaran Telaah Matematika Sekolah Dasar.

\section{METODE PENELITIAN}

Jenis penelitian ini merupakan Penelitian Tindakan Kelas. Pendekatan yang digunakan dalam penelitian ini adalah pendekatan kualitatif. Dalam penelitian ini, tindakan yang dilakukan terangkum pada sebuah siklus dengan setiap satu siklus terdapat empat langkah penelitian yaitu perencanaan, tindakan, pengamatan/observasi, dan refleksi. Sebelum melakukan tindakan terlebih dahulu diadakan studi pendahuluan. Dari hasil observasi pada studi pendahuluan inilah yang akan dijadikan dasar perancangan tindakan. Oleh karena itu, secara garis besar di dalam kegiatan penelitian ini ada tiga tahapan besar yaitu studi pendahuluan, tindakan siklus I, dan tindakan siklus II.

Instrumen penelitian dalam penelitian ini yaitu peneliti sendiri, catatan lapangan, dan lembar penilaian. Peneliti sebagai perencana, pelaksana, penganalisis data, dan pada akhirnya sebagai pelapor hasil penelitian. Catatan lapangan merupakan catatan yang ditulis oleh observer (dosen sekaligus peneliti) mengenai situasi kelas selama pelaksanaan praktik mengajar yang dilakukan oleh mahasiswa. Lembar penilaian pada penelitian ini digunakan untuk mengukur hasil belajar mahasiswa.

Prosedur yang digunakan dalam pengumpulan data pada penelitian ini meliputi catatan lapangan dan lembar penilaian. Catatan lapangan merupakan catatan yang ditulis oleh peneliti mengenai aktivitas mahasiswa selama pembelajaran, baik aktivitas mahasiswa yang melakukan praktik mengajar maupun mahasiswa yang tidak melakukan praktik 
mengajar. Lembar penilaian berisi soal-soal yang harus dikerjakan mahasiswa secara tertulis yang nantinya akan digunakan untuk melihat hasil belajar mahasiswa.

Cara menganalisis data yaitu dengan cara menentukan jumlah skor yang diperoleh pada tes tertulis berdasarkan rubrik penilaian dalam lembar penilian. Kriteria keberhasilan dalam penelitian ini menggunakan acuan keberhasilan hasil belajar mahasiswa yaitu apabila lebih dari 50\% mahasiswa di kelas tersebut mencapai nilai lebih dari 70.

Lokasi yang dipilih pada penelitian ini adalah IKIP Budi Utomo Malang. Sedangkan mahasiswa yang dijadikan objek penelitian adalah mahasiswa semester tiga yang menempuh mata kuliah Telaah matematika SD.

\section{HASIL DAN PEMBAHASAN}

Pelaksanaan pembelajaran whole brain dilaksanakan selama dua siklus, yaitu siklus I dan siklus II. Tahapan pembelajaran whole brain pada siklus I yaitu mahasiswa hanya diberi pengarahan oleh dosen mengenai metode pembelajaran whole brain kemudian mereka diminta langsung praktik mengajar. Sedangkan pada siklus II, sebelum mahasiswa melakukan praktik mengajar, mereka diminta untuk membuat perencanaan mengajar secara tertulis kemudian konsultasi dengan dosen sebelum dilakukan praktik mengajar.

Pada siklus I, beberapa hal mengenai whole brain yang disampaikan dosen kepada mahasiswa diantaranya sebagai berikut. Metode pembelajaran whole brain menekankan pendidik untuk memanfaatkan kegiatan visual, audio dan kinestetik secara bersama, dengan begitu kedua otak dapat bekerja secara maksimal. Pendidik harus memberikan gerakan-gerakan dalam setiap materi pembelajarannya, menyampaikan materi dengan suara yang nyaring dan menarik. Salah satu hal yang harus dilakukan dalam pengajaran dengan metode ini adalah dengan mirror atau peserta didik diajak untuk melihat dan mengikuti mimik pengucapan dan gerakan yang dilakukan oleh pendidik secara menarik dan dilakukan secara berulang dan terus menerus sampai peserta didik dapat memahami materi tersebut. Selain itu metode pembelajaran whole brain memberikan bekal kepada pendidik agar dapat mengatur manajemen kelas dengan baik, diantaranya yaitu pendidik harus dapat mengontrol emosi dan mengenal setiap peserta didik dengan baik, menjadi pengatur manajemen kelas yang baik sebelum pelajaran, mencintai pekerjaan yang telah dipercayakan kepadanya, menyadari bahwa setiap peserta didik memiliki karakter dan sifat yang unik. Manajemen kelas yang baik mempengaruhi kondisi pembelajaran dan penerimaan materi pembelajaran. Metode pembelajaran ini menuntut pendidik untuk 
memberikan peraturan-peraturan sebelum mereka mengajar, menyebutkannya di dalam kelas dengan disertai gerakan-gerakan yang sesuai dengan peraturan tersebut dan peserta didik wajib mengingat dan menyampaikannya sebelum pelajaran dimulai, agar peserta didik dapat mengerti kondisi yang terjadi di dalam kelas selama pembelajaran. Peraturan dasar yang dapat diberikan diantaranya yaitu mendengarkan guru selama guru berbicara, mengikutikuti arahan dengan cepat, mengangkat tangan sebelum berbicara, harus berkata jujur, buatlah gurumu senang, dan sebagainya. Peraturan dapat dibuat secara menarik atau ditempel di dalam kelas agar peserta didik dapat terus membaca dan mengingatnya. Peraturan yang sederhana dan menyenangkan akan dapat membuat peserta didik mampu menjaga kondisi kelas dengan baik, teratur, dan tertib.

Berdasarkan hasil pengamatan pada siklus I menunjukkan bahwa mahasiswa masih belum sepenuhnya melaksananakan pembelajaran whole brain dengan bagus yaitu mahasiswa yang melakukan praktik mengajar masih belum menggunakan kondisi pembelajaran yang mendukung peserta didik untuk melakukan kegiatan audio, visual, dan kinestetik secra bersama-sama. Itu artinya kedua otak masih belum digunakan secara bersama-sama. Berdasarkan hasil analisis data pada siklus I menunjukkan bahwa pembelajaran yang dilakukan praktikan belum mencapai kriteria keberhasilan karena setelah dilakukan tes formatif, lebih dari 50\% mahasiswa yang mendapat skor kurang dari 70.

Tindakan yang akan dilakukan pada siklus II untuk memperbaiki siklus I yaitu mahasiswa diminta membuat perencanaan mengajar secara tertulis dan melakukan konsultasi sebelum praktik mengajar. Perencanaan mengajar tersebut diantaranya sebagai berikut. Menuliskan materi yang akan dibahas, kegiatan-kegiatan yang akan dilakukan selama pembelajaran dan yang terpenting adalah tujuan yang ingin dicapai. Tujuan pembelajaran harus disampaikan sebelum pelajaran dimulai kepada peserta didik sebagai pengantar materi yang akan disampaikan. Contoh tujuan pembelajaran yaitu memberikan pengarahan hubungan antara materi yang akan dipelajari dengan aplikasinya dalam kehidupan sehari-hari. Tulis kegiatan pembelajaran yang sistematis dari awal hingga akhir dan sertakan penerapan dasar metode whole brain seperti penyampaian peraturan kelas di awal pembelajaran. Selain itu yang paling penting juga, tulis kegiatan yang menggunakan audio, visual, dan kinestetik secara bersama-sama.

Berdasarkan hasil pengamatan siklus II menunjukkan bahwa mahasiswa sudah mampu melakukan pembelajaran whole brain dengan baik karena mahasiswa yang 
melakukan praktik mengajar sudah menggunakan kondisi pembelajaran yang mendukung peserta didik untuk menggunakan kedua otak secara bersama-sama. Contohnya yaitu pembelajaran menggunakan media manual yang mendorong peserta didik harus menggunakan audio, visual, dan kinestetik secara bersama-sama. Selain itu ada juga yang menerapkan kondisi pebelajaran dengan belajar sambil bernyanyi, dengan bernyanyi maka otak kiri akan mempelajari lirik lagu sedangkan otak kanan memahami nada atau musik dari lagu tersebut. Dengan demikian otak kanan dan kiri bekerja bersama-sama. Berdasarkan hasil analisis data pada siklus II menunjukkan bahwa pembelajaran yang dilakukan praktikan sudah mencapai kriteria keberhasilan karena berdasarkan hasil tes formatif diketahui bahwa hasil belajar mahasiswa di kelas tersebut lebih dari $50 \%$ mahasiswa mencapai skor lebih dari 75. Berdasarkan hasil penelitian yang telah dilakukan, diketahui bahwa mahasiswa dapat lebih memahami materi dengan menggunakan metode pembelajaran whole brain dibandingkan metode pembelajaran biasa.

Berdasarkan pelaksanaan tindakan metode pembelajaran whole brain di IKIP Budi Utomo Malang pada pembelajaran mata kuliah Telaah Matematika SD, diketahui beberapa hasil kegiatan pembelajaran. Sebelum menyusun tindakan, dilakukan studi pendahuluan untuk melihat kondisi pembelajaran yang tidak menggunakan metode whole brain. Dosen meminta mahasiswa untuk melakukan praktik mengajar tanpa menuntut metode pembelajaran yang harus digunakan. Dosen hanya memberi arahan agar mahasiswa melakukan praktik mengajar dengan baik, metode pembelajaran yang bagus dan menarik serta konsep dapat tersampaikan dengan benar dan bagus. Setelah beberapa konsep matematika SD disampaikan melalui praktik mengajar yang dilakukan oleh beberapa mahasiswa, dilakukan tes formatif untuk menguji kemampuan mahasiswa di kelas tersebut. Dari hasil tes ditemukan bahwa lebih dari 50\% mahasiswa di kelas tersebut mendapat skor kurang dari 50. Hal-hal yang ditemukan pada studi pendahuluan inilah yang menjadi kondisi awal kemampuan matematika mahasiswa. Kondisi tersebut digunakan sebagai dasar untuk mengetahui pelaksanaan tindakan penelitian dapat meningkatkan kemampuan matematika mahasiswa atau tidak.

Banyak perubahan yang terjadi pada pembelajaran dengan menggunakan metode whole brain jika dibandingkan pada saat studi pendahuluan. Mahasiswa yang praktik mengajar menjadi lebih kreatif dalam melakukan praktik mengajar dan berdasarkan hasil tes formatif diketahui bahwa lebih dari 50\% mahasiswa mencapai skor lebih dari 50 . Namun masih kurang dari 50\% mahasiswa di kelas tersebut yang mendapat skor lebih dari 
70. Sehinggga meskipun pada siklus I sudah ada peningaktan daripada saat studi pendahuluan, masih perlu dilakukan tindakan siklus II.

Tindakan yang telah dilakukan pada siklus I dinilai masih terdapat beberapa kelemahan. Kelemahan-kelemahan tersebutlah yang akan diperbaiki pada tindakan siklus II. Kelemahan-kelemahan dalam pelaksanaan pembelajaran yang telah dilakukan dapat ditemukan setelah melakukan refleksi kegiatan. Tindakan yang dilakukan pada siklus II merupakan tindakan yang direncanakan berdasarkan hasil refleksi siklus I. Pada kegiatan refleksi tersebut ditemukan kelemahan yang pada tindakan siklus I seperti mahasiswa sudah merasa bagus persiapan untuk praktik mengajar, namun saat praktik mengajar ditemukan bebeapa kendala di luar dugaan. Sehingga dosen perlu memperhatikan persiapan praktik mengajar mahasiswanya sebelum dilakukan praktik mengajar di hadapan teman-temannya. Berdasarkan kelemahan-kelemahan tersebut, maka disusun tindakan pada siklus II dengan meminta mahasiswa untuk menuliskan rencana-rencana yang akan dilakukan untuk praktik mengajar. Pada siklus II ini mahasiswa lebih matang persiapan mengajarnya. Sehingga lebih bagus dan menarik dalam kegiatan pembelajaran saat melakukan praktik mengajar. Selain itu, konsep matematika dapat tersampaikan dengan lebih baik. Hal ini dapat terlihat dari hasil belajar yang dicapai setelah dilakukan tes formatif. Berdasarkan hasil tes formatif diketahui bahwa lebih dari 50\% mahasiswa mencapai skor lebih dari 75. Seperti yang diungkapkan Sanjaya (2007:145) bahwa keberhasilan implementasi dari metode pembelajaran yang digunakan secara tepat oleh pendidik dapat terlihat dari setiap hasil pembelajaran peserta didik.

Setiap penerapan dasar dalam metode whole brain dapat diaplikasikan untuk seluruh pembelajaran. Kunci dari metode whole brain adalah membuat peserta didik terlibat aktif dalam pembelajaran dan membuat pembelajaran matematika menjadi pembelajaran yang menyenangkan. Dengan pengaturan manajemen kelas yang tepat terlebih dahulu, maka setiap pembelajaran dapat berjalan dengan baik.

Pembelajaran matematika yang penuh dengan rumus dan konsep dapat dibuat ke dalam satu pembelajaran menarik yang mendorong sistem visual, audiotori dan kinestetik perserta didik secara bersama. Dengan begitu, peserta didik tidak hanya dapat menghafalkan setiap rumus tapi juga dapat mengerti konsep matematika dengan benar dan dapat mengembangkannya.

\section{KESIMPULAN}


Berdasarkan hasil analisis data penelitian dan pembahasan yang telah diuraikan, dapat ditarik kesimpulan bahwa metode pembelajaran yang dapat meningkatkan hasil belajar mahasiswa adalah metode pembelajaran whole brain yang mana pengelolaan manajemen kelas harus tertata dengan baik serta peserta didik harus diajak melakukan kegiatan audio, visual, dan kinestetik secara bersama-sama.

\section{REKOMENDASI}

Berdasarkan kesimpulan hasil penelitian di atas, saran yang dapat dikemukakan adalah mahasiswa yang akan melakukan praktik mengajar sebaiknya menggunakan metode pembelajaran whole brain dengan perencanaan secara matang mengenai pengelolaan manajemen kelas serta penerapan kegiatan audio, visual, dan kinestetik secara bersamasama dengan mengembangkan kegiatan pembelajaran sesuai dengan kreatifitas masingmasing.

\section{REFERENSI}

Biffle, C. (2013). Whole Brain Teaching For Challenging Kids. America: Lucinda Geist.

Jensen, E. (2010). Guru Super \& Super Teaching Edisi Keempat. Jakarta Barat:

PT. Indeks

Marno \& Idris. (2008). Strategi dan Metode Pengajaran. Jogjakarta: Ar-Ruzz Media.

Moleong, L. J. (2010). Metodologi Penelitian Kualitatif. Bandung: Rosda.

Mulyasa, E. (2008). Implementasi Kurikulum Tingkat Satuan Pendidikan. Jakarta: Bumi Aksara.

Ratumanan, T. G. \& Theresia L. (2011). Penilaian Hasil Belajar pada Tingkat Satuan Pendidikan. Surabaya: Unesa University Press.

Rose \& Nicholl. (2002). Accelerated Learning For The $21^{\text {st }}$ Century : Cara Belajar Cepat Abad XXI. Bandung : Nuansa

Sanjaya, W. (2007). Strategi Pembelajaran Berorientasi Standar Proses Pendidikan. Jakarta: Kencana Prenada Media Group.

Sugiyono. (2012). Memahami Penelitian Kualitatif. Bandung: Alfabeta.

Uno, H. B. (2006). Perencanaan Pembelajaran. Jakarta: PT. Bumi Aksara.

Yamin, M. \& Maisah. (2009). Manajemen Pembelajaran Sekolah. Jakarta: Gaung Persada. 
